\section{JEC J Journal of Eductitional Chemistry}

Journal of Educational Chemistry (1 (1), Juni 2019, 1-8)

Website: http://www.journal.walisongo.ac.id/index.php/jec ISSN 2685-4880

DOI: $10.21580 / \mathrm{jec} \cdot 2019.1 .1 .3830$

\title{
Penerapan Model Blended Learning Untuk Meningkatkan Pemahaman Konsep Termokimia Siswa
}

\author{
Sidiq Subagiyo \\ Sekolah Menengah Atas Negeri 1 Lasem, Rembang \\ E-mail: sidiqsubagiyo@gmail.com
}

\begin{abstract}
This research aims to determine the effectiveness of application the blended learning model to improve students' understanding of thermochemistry concepts. The research method used is a quasi-experimental method with Randomized Posttest Only Control Design. The subjects of this study were students of class XI MIPA Senior High School Lasem. Research data taken in the form of understanding the concept of students through cognitive learning outcomes. Data collection is done through tests, interviews and observations. Sampling uses random sampling technique. The data analysis technique uses an analysis of the related t-test (Independent-Sample T-Test) from the results of the experimental class and control class posttest. The results and analysis that have been done show that the application of blended learning model is effective to improve the understanding of students' thermochemical concepts. This is indicated by the average evaluation value of the concept of thermochemical concepts in the experimental class of 77.3 and the control class of 69.7 and the results of the test are $t_{\text {count }}=-4,672$ and $t_{\text {table }}=-2,037(\alpha=5 \%)$ so $t_{\text {count }}<t_{\text {table. }}$.
\end{abstract}

Keywords: blended learning, thermochemistry, understanding of concept 


\begin{abstract}
Abstrak
Penelitian ini bertujuan untuk mengetahui efektivitas penerapan model blended learning untuk meningkatkan pemahaman konsep termokimia pada siswa. Metode penelitian yang digunakan adalah metode quasi experimental dengan Randomized Posttest Only Control Design. Subyek penelitian ini adalah siswa kelas XI MIPA SMA Negeri 1 Lasem. Data penelitian yang diambil berupa pemahaman konsep siswa melalui hasil belajar kognitif. Pengumpulan data dilakukan melalui tes, wawancara dan observasi. Pengambilan sampel menggunakan teknik random sampling. Teknik analisis data menggunakan analisis uji t-test related (Independent-Sample T-Test) dari hasil posttest kelas eksperimen dan kelas kontrol. Dari hasil dan analisis yang telah dilakukan menunjukkan bahwa penerapan model blended learning efektif untuk meningkatkan pemahaman konsep termokimia siswa. Hal ini ditunjukkan dengan rata-rata nilai evaluasi pemahaman konsep termokimia kelas eksperimen sebesar 77,3 dan kelas kontrol sebesar 69,7 dan pada pengujian juga didapatkan hasil yaitu $t_{\text {hitung }}=-4,672$ dan $t_{\text {tabel }}=-2,037(\alpha=5 \%)$ sehingga $t_{\text {hitung }}<t_{\text {tabel }}$.
\end{abstract}

Kata Kunci: blended learning, termokimia, pemahaman konsep

\title{
Pendahuluan
}

\begin{abstract}
Perkembangan teknologi informasi yang begitu cepat telah mempengaruhi dan memunculkan tuntutan baru dalam bidangbidang kehidupan, salah satunya di bidang pendidikan. Teknologi informasi digunakan untuk menjaring, mengolah dan menyajikan data secara elektronik menjadi informasi menggunakan berbagai format bagi penerimanya (Rahmawati, 2009). Seiring dengan perkembangan teknologi informasi, juga diikuti dengan berkembangnya proses pembelajaran, yang meliputi model, strategi, pendekatan, metode maupun media pembelajaran yang dipakai. Salah satu wujud dari perkembangan teknologi informasi pada bidang Pendidikan adalah pembelajaran secara e-learning.
\end{abstract}

2

Copyright (C) 2019 JEC | ISSN 2685-4880

Volume 1, Nomor 1, Juni 2019

E-learning merupakan sebuah inovasi
yang mempunyai peran terhadap
perkembangan proses pembelajaran secara
online yang memanfaatkan perangkat elektronik
sebagai media penunjang (Afdhila, Nazar dan
Hanum, 2012). Guru mampu menerapkan
pembelajaran e-learning yang dipadukan
dengan pembelajaran tatap muka langsung.
Perpaduan pembelajaran tersebut disebut
blended learning. Blended learning
mempermudah komunikasi, keleluasaan siswa
dalam mengakses bahan ajar dan interaksi
antara guru dan siswa menjadi tidak terbatas.
Menurut Harding, Kaczynski dan Wood
(dalam Aprina, 2009: 5) bahwa blended learning
merupakan pembelajaran r yang
mengintegrasikan pembelajaran rang
menggabungkan berbagai sumber secara fisik

E-learning merupakan sebuah inovasi yang mempunyai peran terhadap perkembangan proses pembelajaran secara online yang memanfaatkan perangkat elektronik sebagai media penunjang (Afdhila, Nazar dan Hanum, 2012). Guru mampu menerapkan pembelajaran e-learning yang dipadukan Perpaduan pembelajaran tersebut disebut blended learning. Blended learning mempermudah komunikasi, keleluasaan siswa dalam mengakses bahan ajar dan interaksi antara guru dan siswa menjadi tidak terbatas.

Menurut Harding, Kaczynski dan Wood (dalam Aprina, 2009: 5) bahwa blended learning merupakan pembelajaran yang menggabungkan berbagai sumber secara fisik 
dan maya (virtual). Blended learning memadukan berbagai metode dan strategi pembelajaran yang menggunakan teknologi virtual (Hadi, 2012). Model ini dapat diberlakukan secara efektif dengan menyesuaikan kondisi yang disepakati antara guru dan siswa. Melalui blended learning, maka pembelajaran berlangsung lebih bermakna karena materi pembelajaran yang disediakan dirancang sedemikian rupa sehingga siswa lebih mudah memahaminya (Sandi, 2012).

Berdasarkan analisis yang dilakukan terhadap hasil Ujian Nasional, menunjukkan bahwa tingkat kesalahan siswa terbanyak adalah pada materi termokimia. Termokimia merupakan materi yang sarat dengan konsep dan aplikasinya pada perhitungan. Pada materi ini siswa masih mengalami kesulitan terutama mengenai cara menentukan $\Delta \mathrm{H}$ reaksi dengan menggunakan hukum Hess dan data perubahan entalpi pembentukan standar ( $\Delta \mathrm{H}$ of $)$ (Mahpuzah, dalam Aprialisa dan Mahdian, 2010). Hasil ini juga oleh penelitian Rovona (dalam Aprialisa dan Mahdian, 2010) bahwa kemampuan siswa dalam menyelesaikan reaksi dan perhitungan $\Delta \mathrm{H}$ reaksi berdasarkan hukum Hess masih kurang. Untuk itu perlu adanya pemilihan dan penggunaan metode dan metode yang tepat dalam menyajikan suatu materi dapat membantu siswa dalam mengetahui serta memahami segala sesuatu yang disajikan guru. Salah satu hal yang bias dilakukan adalah menerapkam model blended learning.

Penggunaan model blended learning mampu memberikan stimulus kepada siswa untuk aktif dan meningkatkan kemandirian belajar (Sandi, 2012). Selain itu model blended learning dapat meningkatkan minat belajar siswa (Budhi, 2013) dan hasil belajar siswa (Afdhila, Nazar dan Hanum 2012). Berdasarkan penelitian dari Wibowo, Supartono dan Supardi (2015) bahwa banyaknya representasi yang harus dikuasai dalam pelajaran kimia, menyebabkan banyak siswa menganggap pelajaran kimia itu konsepnya abstrak dan sulit untuk dipahami. Kesulitan siswa untuk memahami konsep kimia berhubungna erat dengan pemahaman konsep yang dimiliki siswa itu sendiri. Pemahaman konsep merupakan ranah kognitif manusia dan merupakan salah satu faktor yang dibutuhkan untuk belajar siswa, sehingga siswa dapat menyelesaikan permasalahan yang dihadapi saat proses belajar.

Berdasarkan analisis permasalahan di atas, maka dilakukan penelitian untuk melakukan inovasi pembelajaran yang dapat membantu meningkatkan pemahaman konsep melalui pembelajaran yang memberikan kesempatan kepada siswa belajar lebih aktif dan lebih berpartisipasi dalam proses belajar mengajar. Salah satu solusi alternatif inovatif yang dapat dilakukan tersebut dituangkan dalam bentuk penerapan model blended learning pada pembelajaran kimia materi termokimia.

\section{Metode Penelitian}

Jenis penelitian yang digunakan adalah penelitian kuantitatif dengan metode penelitian ini adalah quasi experimental dengan menggunakan kelas eksperimen dan kelas kontrol. Subjek dalam penelitian ini adalah siswa kelas XI MIA SMAN I Lasem. Penerapan model pembelajaran menggunakan 1 kelas sebagai kelas eksperimen dan 1 kelas sebagai kelas kontrol. Desain implentasi menggunakan Randomized Posttest Only Control Design (Creswell, 2009: 161). Setelah data populasi dinyatakan homogen dan berdistribusi normal, maka ditentukan kelas XI MIA 1 sebagai kelas eksperimen dan kelas XI MIA 2 sebagai kelas kontrol.

Teknik yang digunakan dalam penelitian ini adalah teknik pengukuran berupa tes pemahaman konsep. Tes ini berupa soal esai untuk mengetahui pemahaman siswa. Analisis hasil tes ini digunakan untuk mengukur pemahaman konsep siswa sesuai dengan indikator-indikator yang sudah ditentukan. Data yang tertera pada lembar hasil tes merupakan penilaian terhadap jawaban siswa pada post test pada kelas yang dilakukan eksperimen dibandingkan dengan kelas kontrol 
dan untuk memastikannya dilakukan dengan uji $t$-test related (Independent-Sample T-Test) dan $N$-Gain.

\section{Tahap Persiapan}

Langkah-langkah yang dilakukan pada tahap persiapan antara lain: (1) melakukan prariset di SMAN 1 Lasem; (2) merumuskan masalah hasil penelitian pra riset; (3) memberikan solusi yaitu menggunakan model blended learning; (4) mengkaji literatur mengenai model blended learning; (5) membuat perangkat pembelajaran berupa rencana pelaksanaan pembelajaran (RPP); (6) membuat instrumen penelitian tes pemahaman konsep belajar siswa; (7) melakukan validasi perangkat pembelajaran dan instrumen penelitian; (8) merevisi perangkat pembelajaran dan instrumen penelitian berdasarkan hasil validasi dari ahli; (9) mengadakan uji coba instrumen penelitian berupa tes hasil belajar pada siswa kelas XII MIA SMAN 1 Lasem; (10) menganalisis data hasil uji coba tes untuk mengetahui reliabilitas soal.

\section{Tahap Pelaksanaan}

Langkah-langkah yang dilakukan pada tahap pelaksanaan antara lain melakukan pembelajaran aktif dengan model blended learning di kelas eksperimen dan pembelajaran aktif di kelas kontrol. Selanjutnya ialah memberikan tes pemahaman konsep setelah diberikan perlakuan.

\section{Tahap Akhir}

Langkah-langkah yang dilakukan pada tahap akhir antara lain: (1) melakukan analisis data hasil penelitian; (2) melakukan pengumpulan data tambahan untuk mendukung analisis data melalui telaah pustaka; (3) menyusun laporan penelitian dengan mendeskripsikan hasil analisis data dan membuat kesimpulan dari penelitian yang dilakukan.

\section{Hasil Penelitian dan Pembahasan}

Pengujian hipotesis yang telah dilakukan sebelumnya menghasilkan kesimpulan bahwa pemahaman konsep termokimia siswa kelas eksperimen yang menggunakan model blended learning lebih tinggi daripada pemahaman konsep termokimia siswa kelas kontrol. Presentase ketuntasan klasikal pencapaian kelas eksperimen pada semua indikator adalah 75,7\%, sedangkan untuk kelas kontrol pencapaian kentuntasan klasikal adalah 29,4\%. Terdapat perbedaan ketuntasan klasikal sebanyak $46,3 \%$ antara kelas eksperimen dan kelas kontrol. Terdapat perbedaan yang cukup seignifikan dari kedua kelas tersebut dari aspek ketuntasan klasikal. Pada aspek rerata pemahaman konsep termokimia siswa pada kelas eksperimen sebesar 77,3, sedangkan rerata pemahaman konsep termokimia siswa pada kelas kontrol sebesar 69,7. Hal ini sudah menunjukkan dampak yang signifikan.

Pada pengujian juga didapatkan hasil yaitu $t_{\text {hitung }}=-4,672$ dan $t_{\text {tabel }}=-2,037(\alpha=5 \%)$ sehingga $t_{\text {hitung }}<t_{\text {tabel}}$, maka $\mathrm{H} 0$ ditolak, yaitu terdapat perbedaan pemahaman konsep termokimia siswa yang signifikan antara siswa yang diajarkan dengan model blended learning dan yang diajarkan dengan model pembelajaran aktif standar. Perbedaan ini menunjukkan bahwa penerapan model blended learning dalam pembelajaran kimia memberikan pengaruh positif terhadap pemahaman konsep termokimia.

Pada perhitungan $N$-Gain juga menunjukkan perkembangan pemahaman konsep termokimia siswa pada kelas yang menggunakan model blended learning dengan siswa pada kelas yang menggunakan model pembelajaran aktif standar seperti pada Gambar 1, Gambar 2 dan Gambar 3.

4

Copyright (C) 2019 JEC | ISSN 2685-4880

Volume 1, Nomor 1, Juni 2019 


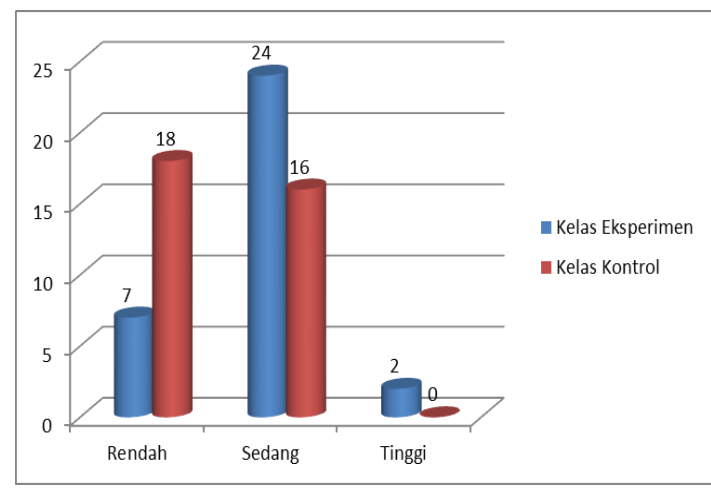

Gambar 1

Rekapitulasi Peningkatan Pemahaman Konsep Termokimia pada Kelas Eksperimen dan Kontrol

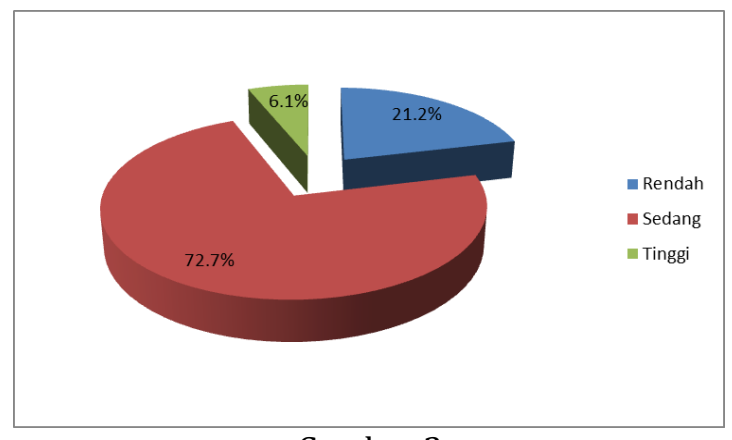

Gambar 2

Persentase Peningkatan Pemahaman Konsep Termokimia pada Kelas Eksperimen

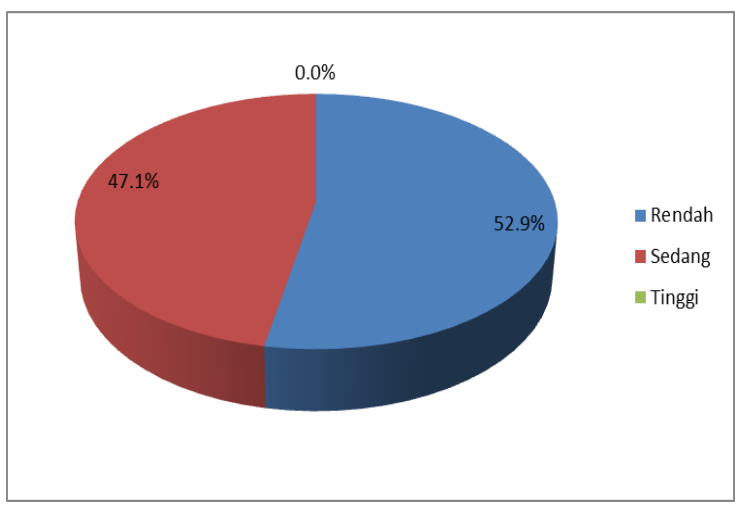

Gambar 3

Presentase Peningkatan Pemahaman Konsep Termokimia pada Kelas Kontrol

Setelah dilakukan pembelajaran menggunakan model blended learning mendapatkan nilai lebih dari KKM dengan ratarata hasil belajar ialah 77,3 dengan ketuntasan klasikal sebesar 75,7\%. Rata-rata hasil belajar disebabkan oleh beberapa hal yaitu dilakukannya pembelajaran dengan model blended learning. Hampir semua siswa pada hasil tes setelah pembelajaran menggunakan model blended learning mampu mengidentifikasi jenis-jenis reaksi eksoterm dan endoterm serta mampu menentukan perubahan entalpinya.

Berdasarkan wawancara dengan siswa, siswa merasa malu dan tidak nyaman untuk menanyakan materi yang masih tidak dimengertinya pada pembelajaran tatap muka, sehingga mereka memilih diam saja. Hal tersebut dapat dilihat pada hasil observasi, saat guru mempersilahkan siswa untuk bertanya tentang materi yang kurang dipahami siswa hanya diam. Siswa juga diam saat guru mempersilahkan siswa untuk bertanya kepada temannya yang maju menyelesaikan contoh soal. Hal ini sesuai dengan Shoimin (2014) dimana metodologi mengajar tradisional menjadikan siswa tidak bebas untuk mengemukakan pendapatnya. Saat diskusi online, guru mempersilahkan siswa untuk bertanya kesulitan yang dialami oleh siswa kepada tutor dalam masing-masing kelompok. Didapat bahwa siswa tidak malu untuk bertanya walaupun siswa tersebut keliru dalam pertanyaannya. Dalam kegiatan pembelajaran jarak jauh online, siswa akan lebih leluasa atau bebas mengungkapkan pendapat atau mengajukan pertanyaan karena tidak ada siswa lainnya yang secara fisik mengamatinya (Munir, 2012).

Diskusi online memberikan kebebasan siswa untuk berpendapat. Berdasarkan penelitian, siswa terlihat leluasa dalam bertanya maupun berpendapat menggunakan bahasa siswa sehari-hari bahkan beberapa siswa berkomentar diluar materi. Disinilah fungsi guru dalam pembelajaran blended learning, dimana guru dapat memantau diskusi yang dilakukan siswa. Blended learning merupakan model pembelajaran online dimana guru dapat mengawasi aktivitas belajar siswa dengan baik. Guru bisa menegur siswa jika siswa mulai berkomentar diluar materi, dan guru bisa 
melihat keaktifan siswa dalam berdiskusi tersebut. Kelebihan pembelajaran online salah satunya adalah pengawasan terhadap pembelajaran perkembangan siswa jadi lebih mudah (Rusman dalam Sari, 2014).

Model blended learning mempermudah siswa untuk lebih leluasa berkomunikasi dengan guru maupun sesama siswa. Berdasarkan hasil wawancara dengan siswa, kemudahan belajar dengan model blended learning disebabkan karena siswa setiap harinya sering bermain media sosial. Hal tersebut sesuai dengan pernyataan Chada Kongchan dalam Hikmah (2017) pembelajaran secara online jauh lebih pribadi dan aman untuk lingkungan belajar.

Belajar secara online membuat siswa dapat melihat lagi hasil diskusi semua kelompok, kesimpulan yang guru berikan, belajar lagi soal di kuis dan mudah mengakses bahan ajar yang ada di library masing-masing siswa. Hal tersebut sesuai dengan Sita (2014), pembelajaran online dapat menyimpan bahan ajar sehingga mudah untuk diakses siswa kapan saja dan dimana saja.

Pada tes tatap muka, berdasarkan hasil wawancara dengan beberapa siswa yang tidak tuntas, didapat informasi bahwa siswa masih belum mengerti dengan materi yang diajarkan. Siswa belum mengerti dengan materi yang diajarkan disebabkan siswa masih kesulitan dalam menuliskan persamaan reaksi termokimia yang merupakan dasar dari materi termokimia tersebut. Sedangkan hasil wawancara dengan beberapa siswa yang tuntas menyatakan bahwa ia sudah paham dengan materi yang diajarkan, namun masih bingung dengan beberapa hal seperti menuliskan reaksi penetralan yang berbeda dari yang diberikan pada contoh. Hasil wawancara tersebut sesuai dengan karakteristik siswa di kelas XII MIA 1, yaitu di dalam satu kelas siswa memiliki kemampuan yang berbeda-beda dalam menangkap materi yang disampaikan. Perbedaan kemampuan siswa dalam

6

Copyright (C) 2019 JEC | ISSN 2685-4880

Volume 1, Nomor 1, Juni 2019 menangkap materi menyebabkan dibutuhkan beberapa kali tatap muka agar semua siswa dalam 1 kelas tersebut dapat memahami materi. Dengan adanya penggabungan tatap muka dan e-learning, siswa dapat menanyakan kesulitan yang dialami siswa pada pembelajaran tatap muka. Pada saat diskusi online, beberapa siswa menanyakan tentang bagaimana menentukan perubahan entalpi reaksi. Hal tersebut sesuai dengan observasi bahwa yang paling banyak siswa diskusikan adalah bagaimana perubahan entalpi reaksi menggunakan cara berbeda-beda yang guru contohkan di papan tulis.

Berdasarkan deskripsi yang dijabarkan, hasil belajar kelas yang menggunakan model blended learning memiliki rerata hasil pemahaman konsep lebih baik daripada kelas yang menggunakan pembelajaran aktif tanpa model blended learning. Hal tersebut sesuai dengan penelitian dari Alfi (2015) dan Alam, (2016) bahwa model pembelajaran blended learning memberikan pengaruh positif dalam meningkatkan hasil belajar siswa. Hasil tersebut disebabkan model blended learning merupakan model yang menggabungkan aspek positif dari pembelajaran tatap muka dan e-learning (Bonk \& Gramaham dalam Hadi, 2012). Aspek positif dari e-learning ialah memastikan fleksibilitas yang tidak dapat dijamin dalam pembelajaran tatap muka (pembelajaran yang tidak terbatas oleh ruang dan waktu) yang memungkinkan guru dan siswa melakukan pembelajaran yang lebih efektif (Kose, 2010), sedangkan aspek positif tatap muka adalah memungkinkan pembelajaran secara interaktif (Hadi, 2012) guru lebih mudah mengontrol keadaan kelas (Majid, 2013).

\section{Simpulan dan Saran}

Simpulan

Berdasarkan hasil penelitian dan pembahasan, diperoleh simpulan tentang penerapan model blended learning dapat meningkatkan pemahaman konsep siswa. Hal ini 
ditunjukkan dengan rata-rata nilai evaluasi pemahaman konsep termokimia kelas eksperimen sebesar 77,3 dan kelas kontrol sebesar 69,7 dan pada pengujian juga didapatkan hasil yaitu $t_{\text {hitung }}=-4,672$ dan $t_{\text {tabel }}=$ $2,037(\alpha=5 \%)$ sehingga $t_{\text {hitung }}<t_{\text {tabel }}$.

\section{Saran}

Berdasarkan penelitian yang sudah dilaksanakan, terdapat beberapa hal yang masih kurang terindentifikasi dengan baik. Oleh karena itu disampaikan beberapa saran yang didasarkan hasil penelitian ini adalah: (1) Perlu adanya penelitian lain yang memfokuskan pada aspek afektif dan psikomorik, karena dalam penelitian ini kurang membahas mengenai aspek tersebut, dan (2) Perlu adanya penelitian lebih lanjut mengenai model pembelajaran lain yang dapat meningkatkan pemahaman konsep siswa, karena proses pemahaman konsep pada penelitian ini belum rinci.

\section{Daftar Pustaka}

Afdhila, R, Nazar, M, dan Hanum, L. 2012. Penerapan Pembelajaran Blended Learning Pada Materi Larutan Penyangga di SMA Negeri 1 Unggul Darul Imarah. Jurnal Ilmiah Mahasiswa Pendidikan Kimia (JIMPK), 2 (3): 165172.

Alam, U. D.; Syarifuddin \& Manurung, B. 2016. Pengaruh Blended Learning Berbasis Edmodo \& Motivasi Belajar Terhadap Hasil Belajar IPA Biologi \& Retensi Siswa Pada Sistem Peredaran Darah Manusia Di Kelas VIII SMAN 5 Medan. Jurnal Pendidikan Biologi, 6 (1): 260-266.

Alfi, S. S. 2015. Pengaruh Model Pembelajaran Blended Learning Terhadap Hasil Belajar Mata Pelajaran IPS Siswa Kelas 8 Di SMAN 36 Jakarta. Skripsi. Makassar: Pendidikan Fisika Jurusan Pendidikan Fisika Pada Fakultas Tarbiyah dan Keguruan UIN Alauddin Makassar.
Aprina. 2009. Penerapan E-learning vs Blended Learning di Dalam Pembelajaran Jarak Jauh. Lampung. Manajemen Jurusan Manajemen Fakultas Ekonomi Universitas Lampung. (Online), (http://blog.unila.ac.id/ adhel/files/2009/06/mini-papersistiminformasi-manajemen2.pdf, diakses 2 januari 2019).

Budhi, J. P. 2013. Penerapan Blended Learning dengan Number Heads Together Untuk Meningkatkan Minat \& Prestasi Belajar pada Materi Kelarutan \& Hasil Kali Kelarutan Siswa Kelas XI IPA 1 SMAN Gondangrejo Tahun Ajaran 2012/2013. Jurnal Pendidikan Kimia, 2 (4): 96-101.

Creswell, J. 2009. Research Design; Qualitative, Quantitative, and Mix Methods Approaches. California: SAGA.

Hadi, A. S. 2012. Teknologi Informasi \& Komunikasi Dalam Pendidikan. Yogyakarta: Graha Ilmu.

Hikmah, N. A. 2017. Efektivitas Media Pembelajaran Edmodo Terhadap Minat Belajar \& Hasil Belajar Siswa Pada Materi Fisika Kelas XI IPA SMAN 1 Ternate Riau. Skripsi. Makassar: Jurusan Pendidikan Fisika Pada Fakultas Tarbiyah dan Keguruan UIN Alauddin Makassar.

Kose, U. 2010. A Blended Learning Model Suported With Web 2.0 Technologi. Jurnal Procedia Social \& Behavioral Sciences, 2 (2): 2794-2802

Majid, A. 2013. Strategi Pembelajaran. Bandung: Rosdakarya.

Munir. 2012. Pembelajaran Jarak Jauh Berbasis Teknologi Informasi dan Komunikasi. Yogyakarta: Alfabeta

Rahmawati, D. 2008. Analisis Faktor-faktor Yang Berpengaruh Terhadap Pemanfaatan Teknologi Informasi. Jurnal Ekonomi \& Pendidikan, 5 (1): 107-118. 
Sandi, G. 2012. Pengaruh Blended Learning Terhadap Hasil Belajar Kimia Ditinjau Dari Kemandirian Siswa. Jurnal Pendidikan Dan Pengajaran, 45 (3): 241251.

Sari, M. 2014. Blended Learning, Model Pembelajaran Abad Ke-21 Di Perguruan Tinggi. Ta'dib, 17 (2): 126-136

Shoimin, A. 2014. 68 Model Pembelajaran Inovatif dalam Kurikulum 2013. Yogyakarta: Ar-Ruzz Media

Sita, D. A \& Elizabeth, M. R. 2014. Penerapan E- learning Melalui Edmodo Untuk Meningkatkan Kemandirian Belajar Simulasi Digital Siswa Kelas X APK 1 SMKN 1 Magentan. Jurnal Admistrasi Perkantoran, 2 (2): 1-21

Wibowo, T, Supartono dan Supardi, K. I. Pengembangan Modul Termokimia dengan Pendekatan Inkuiri Terpadu Pendidikan Karakter untuk Meningkatkan Logika Siswa. Journal of Innovative Science Education, 4 (1): 1-6. 